\title{
Perception of HIV/AIDS Risk Behavior among Students in Central Java Indonesia
}

\author{
Muhammad Azinar ${ }^{1}$, Alfiana Ainun $\mathrm{Nisa}^{2}$, Furqonawati $^{3}$ \\ \{azinar.ikm@mail.unnes.ac.id ${ }^{1}$, alfiana_ainun@mail.unnes.ac.id ${ }^{2}$, furqonawati@gmail.com ${ }^{3}$ \} \\ Universitas Negeri Semarang, Semarang, Indonesia ${ }^{1,2,3}$
}

\begin{abstract}
The prevalence of HIV/AIDS in all regions in Indonesia is always increasing, including in Central Java. This case also often occurs in the group of adolescents aged 15-24 years and having status as students. Cumulatively until 2018, there have been 27,000 students in Central Java indicated as having HIV/AIDS. These risk factors are caused by their behavior, especially premarital sexual behavior. These risky behaviors can be caused by their perception. This research uses descriptive analytic design. The study population was high school students in Central Java. A sample of 322 students was divided proportionally between men and women. Data analysis was performed descriptively and comparatively. The results showed that most students had a moderate perception of HIV/AIDS risk behavior. There is no significant difference in perception between male and female students and there are differences in perceptions between students in urban and rural areas towards HIV/AIDS risk behavior.
\end{abstract}

Keywords : students, risk behavior, HIV / AIDS

\section{Introduction}

AIDS is a disease which until now has become a public health problem in almost all countries in the world, including Indonesia. Every day new cases of HIV/AIDS occur and the number is always increasing. The highest distribution of HIV/AIDS cases occurred in the age group of 20-29 years (32.1\%), the age group of 30-39 years $(31 \%), 40-49$ years $(13.6 \%), 50-59$ years $(5.1 \%)$, and $15-19$ years $(3.2 \%)$. Based on sex, the percentage of HIV/AIDS in men is $58 \%$ and $33 \%$ for women. Meanwhile $9 \%$ did not report gender [1].

Central Java Province is the region that currently has the fifth highest cumulative number of HIV/AIDS in Indonesia. Over the past three years there has been a significant increase in new cases. Since it was first discovered in Central Java until 2018 there have been 23,603 cases, 1,672 of whom died of AIDS [1].

Cases of HIV/AIDS also occur in many groups of adolescents aged 15-24 years and have the status of students. The Central Java AIDS Commission recorded that cumulatively until 2018, there were 27,000 students in Central Java indicated to have HIV/AIDS. Most students are infected with the HIV/AIDS virus because of having same sex or men who have sex with men (MSM) and men with women [2]. 
The facts above show that nationally and regionally in Central Java, adolescents and students who have become a risk group for HIV/AIDS. These risk factors are caused by their behavior, especially premarital sexual behavior. UNICEF estimates that new HIV/AIDS cases in adolescents will continue to increase every year. From 250,000 cases in 2015 will increase to almost 400,000 cases by 2030 and will cause AIDS as the leading cause of adolescents death in the world [3].

Adolescence is the most difficult period for everyone. The most critical developmental period in the stages of human life. The period of adolescent development is characterized by emotional changes, a high curiosity, like to try new things so that it can have an impact on the vulnerability of certain diseases, including HIV/AIDS [4].

Gender influences the risk of HIV/AIDS transmission. Adolescent girls have a greater risk of HIV/AIDS. UNICEF data mentions from 4 new cases of HIV/AIDS in adolescents aged 15 to 19 years, 3 cases of which occurred in adolescent girls [3]. There are differences in perceptions regarding sexuality between boys and girls. Many social norms in society place men as having a higher role and must be followed by women. This social norm that ultimately makes it difficult for women to protect themselves from the risk of HIV/AIDS infection. In addition, in traditional norms, virginity for unmarried adolescent girls has become a barrier for them to seek important sexual health information, including knowledge about HIV risk, so as to maintain their virginity, many adolescents are involved in alternative sexual behavior, such as sex anal, which can also increase the risk of contracting HIV [5].

The residence can also affect adolescent perceptions about the risk of HIV/AIDS. Awareness of how HIV/AIDS can be transmitted. Adolescent girls in urban areas $38 \%$ have a good awareness, while adolescents in rural areas are $24 \%$. The majority of adolescent girls in urban areas know about perceptions that are still wrong regarding HIV/AIDS transmission (43\%) and 36\% adolescent girls who know about ways to protect from HIV/AIDS [6].

The biggest risk factor for HIV / AIDS transmission is caused by risky sexual behavior [7]. Risk behaviors are behaviors that have the potential to put people at danger or risk significant harm [8]. Risk sexual behavior is sexual activity and lifestyle that puts a person at increased risk of suffering from a condition, illness, or injury due to sexual behavior carried out.

Adolescent risk behaviors can be caused by their perception. Regarding the transmission of HIV/AIDS, an individual's perceptions about the risk of HIV infection often influence prevention behaviors such as whether he has an HIV test or uses a condom in sexual activity or does not have unprotected sex. The relationship between perceived risk behavior and the risk of perceived HIV infection is still underappreciated among adolescents [9].

The perception of HIV risk that is still low in adolescents can influence risky sexual behavior. This can be a cause of the spread of HIV infection in adolescents. Adolescents sometimes feel powerless in adopting preventive measures to reduce their health risks. False beliefs will also affect adolescent perceptions about HIV/AIDS risk behavior.

HIV/AIDS transmission prevention behavior is very necessary because the HIV/AIDS epidemic in adolescents in Indonesia is increasing every year. Factors that are significantly related to adolescent behavior towards HIV/AIDS prevention are the level of knowledge and attitudes [10]. 
The Millennium Development Goals (MDGs) have targeted reducing HIV/AIDS eipdemic. In fact at this time the target has not been achieved. Not fully the public knows about HIV/AIDS, including teenagers. Globally, currently adolescents who have comprehensive knowledge about HIV/AIDS only reach $67.3 \%$ in adolescent boys and $66 \%$ in adolescent girls [11]. This program is continued through Sustainable Development Goals (SDGs). The goal is to achieve the target in ending the AIDS epidemic by 2030. Increasing the knowledge and awareness of the community is still being carried out. Good knowledge will support good attitude. Knowledge about HIV/AIDS can influence students to take warnings and make good choices [12]. Adolescents with positive attitudes show good behavior [13]. Attitudes reflect the level of knowledge of an individual.

This study uses descriptive analytic design to describe the characteristics and perceptions of students in preventing HIV/AIDS risk behavior in Central Java, analyzing differences in perceptions about HIV/AIDS risk behavior between male and female students, different perceptions between students in urban and rural areas.

\section{$2 \quad$ Method}

The study population was senior high school students in three regions with the highest rates of HIV/AIDS transmission in Central Java in 2019, that is Jepara, Banyumas and Semarang. The three regions also represent urban and rural areas in the province of Central Java. The total population of this study was 61,749 students. The number of samples is calculated according to the formula for calculating the minimum sample size obtained a sample of 322 students and divided proportionally namely 119 (36.96\%) men and 203 (63.04\%) women.

The data of this study were collected using a questionnaire consisting of two parts, namely characteristics and perceptions about HIV/AIDS risk behavior. Perception scores are categorized into four categories, very low (score 1.00-1.49), low (score 1.50-2.49), moderate (score 2.50-3.00), high (score 3.01-3.49) and very high perception (score 3.50-4.00). Data analysis was performed with a t-test at a probability level of 0.05 to determine differences in perceptions between male and female students, as well as differences in perceptions between students in urban and rural areas. 


\section{Result and Discussion}

\subsection{Perception of HIV/AIDS Risk Behavior among Students in Central Java Indonesia}

Table 1. Perception of HIV/AIDS Risk Behavior among Students in Central Java Indonesia

\begin{tabular}{|c|c|c|c|c|}
\hline $\mathbf{Q}$ & HIV/AIDS Risk Behavior Perception & Mean & SD & Decision \\
\hline 1. & $\begin{array}{l}\text { Avoiding sex relations with people who have many } \\
\text { partners can prevent the transmission of HIV / AIDS }\end{array}$ & 3.74 & 0.56 & Very high \\
\hline 2. & HIV/AIDS can be treated by a traditional physician & 3.54 & 0.60 & Very high \\
\hline 3. & $\begin{array}{l}\text { Living with an uninfected partner will help someone } \\
\text { avoid HIV/AIDS }\end{array}$ & 3.14 & 0.72 & High \\
\hline 4. & Harmless sex with commercial sex workers & 3.60 & 0.67 & Very high \\
\hline 5. & $\begin{array}{l}\text { HIV/AIDS can be transmitted through mosquito and flea } \\
\text { bites }\end{array}$ & 3.05 & 0.70 & High \\
\hline 6. & Antibiotics can be used to treat HIV/AIDS & 2.73 & 0.66 & Moderate \\
\hline 7. & HIV/AIDS can be transmitted through magic & 3.54 & 0.64 & Very high \\
\hline 8. & $\begin{array}{l}\text { Non-screened blood transfusion can make someone } \\
\text { infected with HIV/AIDS }\end{array}$ & 3.35 & 0.61 & High \\
\hline 9. & $\begin{array}{l}\text { HIV/AIDS can be transmitted by using the same toilet as } \\
\text { a Sufferer }\end{array}$ & 2.69 & 0.78 & Moderate \\
\hline 10. & There is a vaccine to protect yourself from HIV/AIDS & 2.40 & 0.78 & Low \\
\hline 11. & $\begin{array}{l}\text { Prayers can protect themselves from HIV/AIDS transmis- } \\
\text { sion }\end{array}$ & 2.23 & 0.78 & Low \\
\hline 12. & $\begin{array}{l}\text { HIV/AIDS is a strategy adopted to reduce sexual activity } \\
\text { in people }\end{array}$ & 2.48 & 0.82 & Low \\
\hline 13. & $\begin{array}{l}\text { Not having sex can make a person not infected with } \\
\text { HIV/AIDS }\end{array}$ & 2.73 & 0.84 & Moderate \\
\hline 14. & $\begin{array}{l}\text { HIV/AIDS can be transmitted through sex without con- } \\
\text { dom }\end{array}$ & 3.34 & 0.66 & High \\
\hline 15. & Having many sex partners is not wrong & 3.46 & 0.77 & High \\
\hline 16. & $\begin{array}{l}\text { Sharing sharp objects (such as razors and needles) can be } \\
\text { a risk for HIV/AIDS transmission }\end{array}$ & 2.83 & 0.81 & Moderate \\
\hline 17. & $\begin{array}{l}\text { Having sex with a person without a condom will be a } \\
\text { high risk of contracting }\end{array}$ & 3.50 & 0.62 & Very high \\
\hline 18. & $\begin{array}{l}\text { Kissing with your mouth outside the sexual area cannot } \\
\text { transmit HIV/AIDS. }\end{array}$ & 2.51 & 0.73 & Moderate \\
\hline 19. & Hugs can transmit HIV/AIDS - & 3.14 & 0.75 & High \\
\hline 20. & Using tableware together can transmit HIV/AIDS & 2.48 & 0.83 & Low \\
\hline 21. & $\begin{array}{l}\text { Having sex with many people with a condom can make a } \\
\text { person not infected with HIV/AIDS }\end{array}$ & 1.00 & 0.00 & Very Low \\
\hline 22. & Herbal medicine can cure AIDS & 2.82 & 0.72 & Moderate \\
\hline 23. & Oral sex can transmit HIV/AIDS & 2.96 & 0.66 & Moderate \\
\hline \multirow[t]{2}{*}{24.} & Anal sex can transmit HIV/AIDS & 3.02 & 0.66 & High \\
\hline & Total & 2.93 & 0.16 & Moderate \\
\hline
\end{tabular}

The results of the study in table 1 show that from the total score $(M=2.93$, $\mathrm{SD}=0.16$ ). This shows that the perception of HIV/AIDS risk behavior among students in Central Java in Indonesia is in the moderate level. The results of this study different from other studies who find that the risk perception among students is high 
[14], and other studies found that adolescent perceptions of HIV risk behavior are generally low $[15,16]$.

The findings of this study also mentioned that of the 322 students, $31.99 \%$ of students already had a high perception of HIV/AIDS risk behavior, and there were still $1.86 \%$ of students who still had low perception. Students in Indonesia do not yet fully have high perceptions about HIV/AIDS risk behavior, one of which is due to the lack of student knowledge about HIV/AIDS. They do not specifically get knowledge of HIV/AIDS through subjects in schools, but they get information about HIV/AIDS through media such as the internet, magazines or counseling that has been followed.

Having sex with many people with a condom can make a person not infected with HIV/AIDS is an example of a perception that many are wrong among teenagers or students in Indonesia. Condoms do not guarantee that they can effectively prevent the transmission of HIV/AIDS, if they are not used correctly and consistently in the changing sexual behavior of partners. In addition, there are still many students who believe that sharing cutlery risks transmitting the HIV virus, as well as many of them stating that the vaccine can to protect themselves from HIV/AIDS.

\subsection{Mean Rating of HIV/AIDS Risk Behavior Perceptions in Male and Female Students in Central Java Indonesia}

Table 2. Mean Rating of HIV/AIDS Risk Behavior Perceptions in Male and Female Students in Central Java Indonesia

\begin{tabular}{|c|c|c|c|c|c|c|c|}
\hline \multirow{2}{*}{$\mathbf{Q}$} & \multirow{2}{*}{ HIV/AIDS Risk Behavior Perception } & \multicolumn{3}{|c|}{ Males } & \multicolumn{3}{|c|}{ Females } \\
\hline & & $\mathbf{M}$ & $\mathbf{S}$ & D & M & $\mathbf{S}$ & D \\
\hline 1. & $\begin{array}{l}\text { Avoiding sex relations with people who } \\
\text { have many partners can prevent the } \\
\text { transmission of HIV / AIDS }\end{array}$ & 3.68 & 0.62 & $\begin{array}{l}\text { Very } \\
\text { high }\end{array}$ & 3.77 & 0.52 & $\begin{array}{l}\text { Very } \\
\text { high }\end{array}$ \\
\hline 2. & $\begin{array}{l}\text { HIV/AIDS can be treated by a traditional } \\
\text { physician }\end{array}$ & 3.58 & 0.64 & $\begin{array}{l}\text { Very } \\
\text { high }\end{array}$ & 3.51 & 0.57 & $\begin{array}{l}\text { Very } \\
\text { high }\end{array}$ \\
\hline 3. & $\begin{array}{l}\text { Living with an uninfected partner will } \\
\text { help someone avoid HIV/AIDS }\end{array}$ & 3.24 & 0.74 & High & 3.08 & 0.71 & High \\
\hline 4. & $\begin{array}{l}\text { Harmless sex with commercial sex } \\
\text { workers }\end{array}$ & 3.53 & 0.76 & $\begin{array}{l}\text { Very } \\
\text { high }\end{array}$ & 3.64 & 0.62 & $\begin{array}{l}\text { Very } \\
\text { high }\end{array}$ \\
\hline 5. & $\begin{array}{l}\text { HIV/AIDS can be transmitted through } \\
\text { mosquito and flea bites }\end{array}$ & 3.03 & 0.75 & High & 3.05 & 0.68 & High \\
\hline 6. & $\begin{array}{l}\text { Antibiotics can be used to treat } \\
\text { HIV/AIDS }\end{array}$ & 2.85 & 0.67 & $\begin{array}{l}\text { Mod- } \\
\text { erate }\end{array}$ & 2.66 & 0.64 & $\begin{array}{l}\text { Moder- } \\
\text { ate }\end{array}$ \\
\hline 7. & $\begin{array}{l}\text { HIV/AIDS can be transmitted through } \\
\text { magic }\end{array}$ & 3.62 & 0.64 & $\begin{array}{l}\text { Very } \\
\text { high }\end{array}$ & 3.49 & 0.63 & High \\
\hline 8. & $\begin{array}{l}\text { Non-screened blood transfusion can } \\
\text { make someone infected with HIV/AIDS }\end{array}$ & 3.32 & 0.66 & High & 3.37 & 0.59 & High \\
\hline 9. & $\begin{array}{l}\text { HIV/AIDS can be transmitted by using } \\
\text { the same toilet as a Sufferer }\end{array}$ & 2.76 & 0.77 & $\begin{array}{l}\text { Mod- } \\
\text { erate }\end{array}$ & 2.64 & 0.79 & $\begin{array}{l}\text { Moder- } \\
\text { ate }\end{array}$ \\
\hline 10. & $\begin{array}{l}\text { There is a vaccine to protect yourself } \\
\text { from HIV/AIDS }\end{array}$ & 2.60 & 0.82 & $\begin{array}{l}\text { Mod- } \\
\text { erate }\end{array}$ & 2.29 & 0.74 & Low \\
\hline 11. & $\begin{array}{l}\text { Prayers can protect themselves from } \\
\text { HIV / AIDS transmission }\end{array}$ & 2.13 & 0.87 & Low & 2.29 & 0.72 & Low \\
\hline 12. & $\begin{array}{l}\text { HIV/AIDS is a strategy adopted to re- } \\
\text { duce sexual activity in people }\end{array}$ & 2.45 & 0.92 & Low & 2.49 & 0.76 & Low \\
\hline 13. & Not having sex can make a person not & 2.80 & 0.94 & Mod- & 2.69 & 0.79 & Moder- \\
\hline
\end{tabular}




\begin{tabular}{|c|c|c|c|c|c|c|c|}
\hline & infected with HIV/AIDS & & & erate & & & ate \\
\hline 14. & $\begin{array}{l}\text { HIV/AIDS can be transmitted through } \\
\text { sex without condom }\end{array}$ & 3.42 & 0.71 & High & 3.29 & 0.63 & High \\
\hline 15. & Having many sex partners is not wrong & 3.29 & 0.86 & High & 3.57 & 0.68 & $\begin{array}{l}\text { Very } \\
\text { high }\end{array}$ \\
\hline 16. & $\begin{array}{l}\text { Sharing sharp objects (such as razors and } \\
\text { needles) can be a risk for HIV/AIDS } \\
\text { transmission }\end{array}$ & 2.81 & 0.92 & $\begin{array}{l}\text { Mod- } \\
\text { erate }\end{array}$ & 2.85 & 0.75 & $\begin{array}{l}\text { Moder- } \\
\text { ate }\end{array}$ \\
\hline 17. & $\begin{array}{l}\text { Having sex with a person without a } \\
\text { condom will be a high risk of contracting }\end{array}$ & 3.58 & 0.59 & $\begin{array}{l}\text { Very } \\
\text { high }\end{array}$ & 3.46 & 0.63 & High \\
\hline 18. & $\begin{array}{l}\text { Kissing with your mouth outside the } \\
\text { sexual area cannot transmit HIV/AIDS. }\end{array}$ & 2.49 & 0.79 & Low & 2.53 & 0.69 & $\begin{array}{l}\text { Moder- } \\
\text { ate }\end{array}$ \\
\hline 19. & Hugs can transmit HIV/AIDS & 3.18 & 0.78 & High & 3.11 & 0.74 & High \\
\hline 20. & $\begin{array}{l}\text { Using tableware together can transmit } \\
\text { HIV/AIDS }\end{array}$ & 2.60 & 0.86 & $\begin{array}{l}\text { Mod- } \\
\text { erate }\end{array}$ & 2.42 & 0.81 & Low \\
\hline 21. & $\begin{array}{l}\text { Having sex with many people with a } \\
\text { condom can make a person not infected } \\
\text { with HIV/AIDS }\end{array}$ & 1.00 & 0.00 & $\begin{array}{l}\text { Very } \\
\text { low }\end{array}$ & 1.00 & 0.00 & $\begin{array}{l}\text { Very } \\
\text { low }\end{array}$ \\
\hline 22. & Herbal medicine can cure AIDS & 2.89 & 0.73 & $\begin{array}{l}\text { Mod- } \\
\text { erate }\end{array}$ & 2.78 & 0.71 & $\begin{array}{l}\text { Moder- } \\
\text { ate }\end{array}$ \\
\hline 23. & Oral sex can transmit HIV/AIDS & 2.90 & 0.73 & $\begin{array}{l}\text { Mod- } \\
\text { erate }\end{array}$ & 3.00 & 0.62 & $\begin{array}{l}\text { Moder- } \\
\text { ate }\end{array}$ \\
\hline 24. & Anal sex can transmit HIV/AIDS & 2.96 & 0.81 & $\begin{array}{l}\text { Mod- } \\
\text { erate }\end{array}$ & 3.05 & 0.56 & High \\
\hline & Total & 2.95 & 0.18 & $\begin{array}{l}\text { Mod- } \\
\text { erate }\end{array}$ & 2.92 & 0.16 & $\begin{array}{l}\text { Mod- } \\
\text { erate }\end{array}$ \\
\hline
\end{tabular}

Table 2 shows that from the total score it was found that in male students $(\mathrm{M}=$ $2.95, \mathrm{SD}=0.18)$ and in female students $(\mathrm{M}=2.92, \mathrm{SD}=0.16)$. This indicates that both male and female student groups in Central Java in Indonesia have perceptions of HIV/AIDS risk behavior in the moderate levels.

Table 3. Comparison of mean rating of HIV/AIDS risky behavior perceptions in male and female students

\begin{tabular}{lccccccc}
\hline Gender & N & Mean & SD & T & Df & $\begin{array}{c}\text { Sig (2- } \\
\text { tailed) }\end{array}$ & 95\% CI \\
\hline Male & 119 & 2.94 & 0.24 & 1.16 & 320 & 0.265 & $-0.022-0.081$ \\
\hline Female & 203 & 2.91 & 0.21 & & & & \\
\hline
\end{tabular}

Table 3 shows that from the T-test analysis, $\mathrm{p}$ values $(p=0.265)$ is greater than 0.05 level of significance. This means that there is no significant difference between perceptions of HIV/AIDS risk behavior between male and female students in Central Java Indonesia, $\mathrm{t}(320)=1.16, p=0.265$. The results of this study support the research of Bernedeth N. Ezegbe et al, which states there is no significant difference between the average level of perception about the risk of HIV / AIDS in male and female students in secondary schools [17].

But the results of this study contradict Kibombo, et al, who found that there were significant differences in perceptions of HIV/AIDS risk behaviors between men and women [16]. Other studies by Bhasin, who revealed that there were significant differences between men and women in the perception of the risk of HIV infection. Women have more positive perceptions about HIV/AIDS risk behavior compared to men [18]. 
Likewise, Steinberg and Monahan's, study found that gender factors greatly influenced a person's risk behaviors and women were found to be more receive to the effects of these risk behaviors than men [19].

\subsection{Mean Rating of HIV/AIDS Risk Behavior Perceptions in Urban and Rural Students in Central Java Indonesia}

Table 4. Mean Rating of HIV/AIDS Risk Behavior Perceptions in Urban and Rural Students in Central Java Indonesia

\begin{tabular}{|c|c|c|c|c|c|c|c|}
\hline \multirow{2}{*}{$\mathbf{Q}$} & \multirow{2}{*}{ HIV/AIDS Risk Behavior Perception } & \multicolumn{3}{|c|}{ Urban } & \multicolumn{3}{|c|}{ Rural } \\
\hline & & $\mathbf{M}$ & $\mathbf{S}$ & D & $\mathbf{M}$ & $\mathbf{S}$ & $\mathbf{D}$ \\
\hline 1. & $\begin{array}{l}\text { Avoiding sex relations with people who } \\
\text { have many partners can prevent the } \\
\text { transmission of HIV / AIDS }\end{array}$ & 3.72 & 0.58 & $\begin{array}{l}\text { Very } \\
\text { high }\end{array}$ & 3.76 & 0.54 & $\begin{array}{l}\text { Very } \\
\text { high }\end{array}$ \\
\hline 2. & $\begin{array}{l}\text { HIV/AIDS can be treated by a tradition- } \\
\text { al physician }\end{array}$ & 3.58 & 0.59 & $\begin{array}{l}\text { Very } \\
\text { high }\end{array}$ & 3.49 & 0.60 & High \\
\hline 3. & $\begin{array}{l}\text { Living with an uninfected partner will } \\
\text { help someone avoid HIV/AIDS }\end{array}$ & 3.19 & 0.70 & High & 3.08 & 0.75 & High \\
\hline 4. & $\begin{array}{l}\text { Harmless sex with commercial sex } \\
\text { workers }\end{array}$ & 3.57 & 0.72 & $\begin{array}{l}\text { Very } \\
\text { high }\end{array}$ & 3.63 & 0.61 & $\begin{array}{l}\text { Very } \\
\text { high }\end{array}$ \\
\hline 5. & $\begin{array}{l}\text { HIV/AIDS can be transmitted through } \\
\text { mosquito and flea bites }\end{array}$ & 3.12 & 0.72 & High & 2.96 & 0.67 & $\begin{array}{l}\text { Moder- } \\
\text { ate }\end{array}$ \\
\hline 6. & $\begin{array}{l}\text { Antibiotics can be used to treat } \\
\text { HIV/AIDS }\end{array}$ & 2.81 & 0.67 & $\begin{array}{l}\text { Mod- } \\
\text { erate }\end{array}$ & 2.62 & 0.64 & $\begin{array}{l}\text { Moder- } \\
\text { ate }\end{array}$ \\
\hline 7. & $\begin{array}{l}\text { HIV/AIDS can be transmitted through } \\
\text { magic }\end{array}$ & 3.61 & 0.58 & $\begin{array}{l}\text { Very } \\
\text { high }\end{array}$ & 3.45 & 0.69 & High \\
\hline 8. & $\begin{array}{l}\text { Non-screened blood transfusion can } \\
\text { make someone infected with HIV/AIDS }\end{array}$ & 3.37 & 0.63 & High & 3.32 & 0.60 & High \\
\hline 9. & $\begin{array}{l}\text { HIV/AIDS can be transmitted by using } \\
\text { the same toilet as a Sufferer }\end{array}$ & 2.77 & 0.76 & $\begin{array}{l}\text { Mod- } \\
\text { erate }\end{array}$ & 2.58 & 0.79 & $\begin{array}{l}\text { Moder- } \\
\text { ate }\end{array}$ \\
\hline 10. & $\begin{array}{l}\text { There is a vaccine to protect yourself } \\
\text { from HIV/AIDS }\end{array}$ & 2.45 & 0.78 & Low & 2.35 & 0.79 & Low \\
\hline 11. & $\begin{array}{l}\text { Prayers can protect themselves from } \\
\text { HIV / AIDS transmission }\end{array}$ & 2.26 & 0.83 & Low & 2.20 & 0.71 & Low \\
\hline 12. & $\begin{array}{l}\text { HIV/AIDS is a strategy adopted to re- } \\
\text { duce sexual activity in people }\end{array}$ & 2.48 & 0.84 & Low & 2.47 & 0.80 & Low \\
\hline 13. & $\begin{array}{l}\text { Not having sex can make a person not } \\
\text { infected with HIV/AIDS }\end{array}$ & 2.75 & 0.85 & $\begin{array}{l}\text { Mod- } \\
\text { erate }\end{array}$ & 2.71 & 0.84 & $\begin{array}{l}\text { Moder- } \\
\text { ate }\end{array}$ \\
\hline 14. & $\begin{array}{l}\text { HIV/AIDS can be transmitted through } \\
\text { sex without condom }\end{array}$ & 3.39 & 0.66 & High & 3.26 & 0.66 & High \\
\hline 15. & Having many sex partners is not wrong & 3.43 & 0.78 & High & 3.50 & 0.74 & $\begin{array}{l}\text { Very } \\
\text { high }\end{array}$ \\
\hline 16. & $\begin{array}{l}\text { Sharing sharp objects (such as razors } \\
\text { and needles) can be a risk for HIV/AIDS } \\
\text { transmission }\end{array}$ & 2.84 & 0.82 & $\begin{array}{l}\text { Mod- } \\
\text { erate }\end{array}$ & 2.82 & 0.80 & $\begin{array}{l}\text { Moder- } \\
\text { ate }\end{array}$ \\
\hline 17. & $\begin{array}{l}\text { Having sex with a person without a } \\
\text { condom will be a high risk of contracting }\end{array}$ & 3.52 & 0.60 & $\begin{array}{l}\text { Very } \\
\text { high }\end{array}$ & 3.48 & 0.64 & High \\
\hline 18. & $\begin{array}{l}\text { Kissing with your mouth outside the } \\
\text { sexual area cannot transmit HIV/AIDS. }\end{array}$ & 2.49 & 0.77 & Low & 2.54 & 0.68 & $\begin{array}{l}\text { Moder- } \\
\text { ate }\end{array}$ \\
\hline 19. & Hugs can transmit HIV/AIDS & 3.29 & 0.70 & High & 2.94 & 0.78 & $\begin{array}{l}\text { Moder- } \\
\text { ate }\end{array}$ \\
\hline 20. & $\begin{array}{l}\text { Using tableware together can transmit } \\
\text { HIV/AIDS }\end{array}$ & 2.57 & 0.85 & $\begin{array}{l}\text { Mod- } \\
\text { erate }\end{array}$ & 2.37 & 0.80 & Low \\
\hline
\end{tabular}




\begin{tabular}{|c|c|c|c|c|c|c|c|}
\hline 21. & $\begin{array}{l}\text { Having sex with many people with a } \\
\text { condom can make a person not infected } \\
\text { with HIV/AIDS }\end{array}$ & 1.00 & 0.00 & $\begin{array}{l}\text { Very } \\
\text { low }\end{array}$ & 1.00 & 0.00 & $\begin{array}{l}\text { Very } \\
\text { low }\end{array}$ \\
\hline 22. & Herbal medicine can cure AIDS & 2.87 & 0.69 & $\begin{array}{l}\text { Mod- } \\
\text { erate }\end{array}$ & 2.75 & 0.75 & $\begin{array}{l}\text { Moder- } \\
\text { ate }\end{array}$ \\
\hline 23. & Oral sex can transmit HIV/AIDS & 2.97 & 0.66 & $\begin{array}{l}\text { Mod- } \\
\text { erate }\end{array}$ & 2.94 & 0.66 & $\begin{array}{l}\text { Moder- } \\
\text { ate }\end{array}$ \\
\hline \multirow[t]{2}{*}{24.} & Anal sex can transmit HIV/AIDS & 3.02 & 0.69 & High & 3.01 & 0.62 & High \\
\hline & Total & 2.96 & 0.17 & $\begin{array}{l}\text { Mod- } \\
\text { erate }\end{array}$ & 2.88 & 0.16 & $\begin{array}{l}\text { Mod- } \\
\text { erate }\end{array}$ \\
\hline
\end{tabular}

Based on the total score in table 4, it is known that the students who live in urban areas $(M=2.96, S D=0.17)$ and students who live in rural areas $(M=2.88, S D=$ $0.16)$. This indicates that students from urban and rural areas have a moderate perception of HIV/AIDS risk behavior.

Table 5. Comparison of mean rating of HIV/AIDS risky behavior perceptions in rural and urban students

\begin{tabular}{lccccccc}
\hline Location & $\mathbf{N}$ & Mean & SD & T & Df & $\begin{array}{c}\text { Sig (2- } \\
\text { tailed) }\end{array}$ & 95\% CI \\
\hline Urban & 180 & 2.96 & 0.22 & 3.04 & 320 & 0.003 & $0.027-0.126$ \\
\hline Rural & 142 & 2.88 & 0.22 & & & & \\
\hline
\end{tabular}

Table 5 shows that from the T-test analysis, $\mathrm{p}$ values $(p=0.003)$ is less than 0.05 level of significance. This means that there is a significant difference between perceptions of HIV/AIDS risk behavior between students living in urban areas and students living in rural areas in Central Java Indonesia, t (320) $=3.04, p=0.003$. This study found that students who live in urban areas tend to have a better perception than students who live in rural areas.

The results of this study contradict Danjin and Onajole, who found that there were no significant differences between levels of awareness about HIV/AIDS among respondents in urban and rural areas [20]. But on the contrary, the results of this study support the opinion of Vaghela, which states urban teenagers have higher perceptions about HIV/AIDS risk behavior than rural teenagers [21]. This study also supports Bernedeth N. Ezegbe et al, who found a significant difference in the average ranking of perceptions of HIV/AIDS risk among urban and rural secondary school adolescents [17].

\section{Conclusion}

The results of this study conclude that the perception of HIV/AIDS risk behavior among students in Central Java in Indonesia is at a moderate level. There is no significant difference between the level of perception about HIV/AIDS risk behavior between male and female students in Central Java, Indonesia. Both tendencies have a moderate level of perception. However it was found, there was a significant difference in the average rank of adolescents in urban and rural areas in schools with regard 
to their perceptions about HIV/AIDS risk behavior. Students in urban areas have better perceptions than students in rural areas.

Further studies can be carried out using a larger population to support the urgency of counseling programs according to the needs of students in senior high school about HIV/AIDS risk behavior. Further research can also be focused on factors that influence adolescent perceptions of risks that make them vulnerable to HIV/AIDS.

\section{References}

[1]. Director General of P2PL, Ministry of Health. Statistics on HIV / AIDS Cases in Indonesia Trimester IV of 2018. Jakarta: Ministry of Health of the Republic of Indonesia; 2018

[2]. Central Java AIDS Commission. HIV / AIDS data in Central Java. Semarang: KPA Central Java; 2019

[3]. UNICEF. Every three minutes a teenage girl is infected by HIV. Retrieved from https://www.unicef.org/wca/press-releases/every-three-minutes-teenage-girl-infected-hivunicef; 2018

[4]. Smriti N., \& Marfatia, Y. S. Adolescent HIV/AIDS: (Issues and challenges). Indian Journal of Sexually Transmitted Diseases, 2010; 31(1), 1-29. https://doi.org/10.4103/ 02537184.68993.

[5]. Gupta, R. Gender, Sexuality, and HIV/AIDS: the what, the why, and the how. Plenary Address for the $13^{\text {th }}$ International AIDS Conference, Durban, South Africa; 2000.

[6]. Vaghela, K. J. A Study of Awareness of HIV/AIDS among Adolescents: (Girls and Boys of Urban and Rural Area). The International Journal of Indian Psychology, 2015; 3, 886.

[7]. Centers for Disease Control and Prevention. HIV Risk Behaviors. Retrieved from https://www.cdc.gov/hiv/risk/estimates/riskbehaviors.html; December 4, 2015.

[8]. Zwar, N. A., Mendelsohn, C. P., \& Richmond, R. L. Supporting smoking cessation. BMJ, 2014; 348, f7535. https://doi.org/10.1136/bmj.f7535

[9]. Akwara P. A., Madise, N. J., \& Hinde, A. Perception of Risk of HIV/AIDS And Sexual Behaviour In Kenya. Journal of Biosocial Science, 2003; 35(3), 385-411. https://doi.org/10.1017/S0021932003003857

[10]. Nugrahawati et al. 2019. Factors Related to Adolescent Behavior in HIV/AIDS Prevention. Kesmas: National Public Health Journal, 2019; 13 (4): 195-201 DOI:10.21109/kesmas.v13i4.2698

[11]. Stalker P. Millennium development goals; 2008. p. 7

[12]. Setyarini AI, Titisari I, Ramadhania PA. Hubungan pengetahuan remaja tentang HIV/AIDS dengan sikap pencegahan HIV/AIDS di SMA Negeril Gurah Kabupaten Kediri. Jurnal Ilmu Kesehatan. 2016; 4 (2); 25-33

[13]. Aung Z, Anisah, Wee KW, Kyin H, Than N, Kamil, et al. Cross sectionalstudy of knowledge, attitude, and practice on HIV infection amongsecondary school students in Kuala Terengganu. International Journalof Medicine and Medical Sciences. 2013; 4 (4); 1335-1346.

[14]. Adogu, P., Udigwe, I., Nwabueze, A., Adinma, E., Udigwe, G., \& Onwasigwe, C. (2015). Sexual health knowledge, attitude and risk perception among in-school and out-of-school female adolescents in Onitsha, Anambra State, Nigeria. South Eastern European Journal of Public Health, 2(1).

[15]. Darteh, E. K., Kumi-Kyereme, A., \& Awusabo-Asare, K. (2016). Perception of Risk of HIV among Adolescents' Living in an Urban Slum in Ghana. African Journal of Reproductive Health, 20(1), 62-70

[16]. Kibombo, R., Neema, S., \& Ahmed, F. H. (2007). Perceptions of risk to HIV infection among adolescents in Uganda: are they related to sexual behaviour?. African Journal of Reproductive Health, 11(3), 168. https://doi.org/10.2307/25549738 
[17]. Bernedeth N. Ezegbe et al. Perception of Risk Behaviours Influencing HIV and AIDS Prevention and Control among Secondary School Adolescents in Enugu State, Nigeria. Global Journal of Health Science, 2019, 11 (6).

[18]. Bhasin, S., Storer, T. W., Berman, N., Callegari, C., Clevenger, B., Phillips, J., ... \& Casaburi, R. (1996). The effects of supraphysiologic doses of testosterone on muscle size and strength in normal men. New England Journal of Medicine, 335(1), 1-7. https://doi.org/10.1056/NEJM199607043350101

[19]. Steinberg, L., \& Monahan, K. C. (2007).Age differences in resistance to peer influence. Developmental Psychology, 43(6), 1531. https://doi.org/10.1037/0012-1649.43.6.1531

[20]. Danjin, M., \& Onajole, A. (2009). HIV/AIDS Risk Behavioural Tendencies Among Secondary School Students in Gombe (Nigeria). The Internet Journal of Health, 11(1).

[21]. Vaghela, K. J. (2015). A Study of Awareness of HIV/AIDS among Adolescents: (Girls and Boys of Urban and Rural Area). The International Journal of Indian Psychology, 3, 886 